\title{
Analysis of the Resource Management Ability by Catfish Farmers in Nigeria: A Case of Ogbaru Local Government Area, Anambra State
}

 \\ Onyekineso Chimnedum Johnpaul ${ }^{4}$
}

${ }^{1}$ IFAD Assisted Anambra State Value Chain Development Programme, Awka, Nigeria

${ }^{2}$ Department of Agricultural Education, Federal College of Education (Technical), Umunze, Nigeria

${ }^{3}$ Department of Agricultural Economics and Extension, Nnamdi Azikiwe University, Awka, Nigeria

${ }^{4}$ Department of Cooperative Economics and Management, Nnamdi Azikiwe University, Awka, Nigeria

Email address:

obianefoca@gmail.com (O. C. Aloysius)

${ }^{*}$ Corresponding author

\section{To cite this article:}

Obianefo Chukwujekwu Aloysius, Nwike Chukwudi Matthew, Anumudu Oluchi Odinaka, Onyekineso Chimnedum Johnpaul. Analysis of the Resource Management Ability by Catfish Farmers in Nigeria: A Case of Ogbaru Local Government Area, Anambra State. International Journal of Agricultural Economics. Vol. 5, No. 5, 2020, pp. 156-164. doi: 10.11648/j.ijae.20200505.12

Received: August 15, 2020; Accepted: August 25, 2020; Published: September 3, 2020

\begin{abstract}
The study was on the analysis of the resource management ability by catfish farmers in Nigeria: A case of Ogbaru Local Government Area, Anambra State. The study focused on the five objectives which investigated the socioeconomic characteristics, costs and net returns, production function, determinants of the returns, resource use efficiency of the farmers, and the challenges facing fish farmers. Data for the study was collected from a cross-section of 240 randomly selected catfish farmers using a well-structured questionnaire and facial interview. The study was able to reveal that male (72.1\%) farmers dominated the industry. The study recorded an average age, household size, level of education, farming experience, and output as 46 years, 11 people, 11 years, 13 years and 5.297 tons respectively. Fish farming was profitable with a net returns of $5,057.02$ USD and returns on investment of 1.82 implying 1.82 USD returns upon every USD investment. The double-log was the lead functional form for the production functions, pond size $(2.64)^{* *}$, utilities $(1.99)^{* *}$, fingerlings $(2.92)^{* * *}$, fertilizer ($1.97)^{* *}$, and labour $(-3.31)^{* * *}$ were the significant production factors. The ratio of Marginal Value Product (MVP) to Marginal Factor Cost (MFC) was less than one for all the resources used apart from fingerlings cost which was greater than one. The relationship between net returns and socioeconomic variables, semi-log was the lead equation and sex, farming experience, level of education, household size, and primary occupation were the significant variables. Furthermore, the study identified the following grey areas inherent in fish farming in the area to include; high cost of feed among others.
\end{abstract}

Keywords: Catfish Farming, Management, Optimal Allocation, Relative Change, Marginal Value Product, Efficiency

\section{Introduction}

Fish farming is very important in the economic development of many nations. It plays an important role in the diets, livelihoods, and income of many developing countries. It is well accepted that fish is a good source of animal protein and a major source of vitamins and minerals to the human body [1], the Federal Department of Fisheries (FDF) assert that, the fact that fish is found in most water bodies around the world makes it readily accessible, cheap and a renewable form of resources found in wide coverage [2].

The consistent increase in the world population resulted to a serious increase in the demand for animal protein, essentially higher in quantity than plant protein. The nutritional requirement in the developing countries are particularly critical when compared to the developed countries [3]. Malnutrition and starvation are the major problems faced by Millions of rural dwellers in the developing countries such as Nigeria. Since fish avails the 
cheap source of animal protein, its demand in Nigeria due to the continuous population growth has not been able to matchup. The Food and Agricultural Organization Statistics (FAO) in 2018 reported that Nigeria population was estimated at about 193.976 million people with an estimated annual per capita fish consumption of $17.5 \mathrm{~kg}$. Therefore, projecting annual fish demand of 3.61 million metric tonnes [4]. As the most populous country in Africa, Nigeria is the largest consumer of fish products in Africa. The country has relied on importation of fish to meet her ever increasing demand. Over USD 1.2 billion is spent annually to offset the deficit demand-supply gap [1]. Annual fish demand and supply in Nigeria was projected as 3.48 million metric tonnes and 1.95 million metric tonnes respectively, this leaves a demand-supply deficit of 43.9 per cent $[4,1]$. This empirical result suggested that employment opportunities abound in the fishery subsector of the Nigerian economy.

The three sources of fish production in Nigeria include; artisanal (inland rivers, lakes, coastal and brackish water), industrial fishing and aquaculture (fish farm) [5-7]. The domestic fish contributions of the three sources over the years explicitly involves; 67.7 per cent artisanal, 30.8 per cent aquaculture and 1.5 per cent industrial fishery [5]. This fact affirmed the assertion of [6], who noted that the majority of fishes supplied to the markets in most cases come from the artisanal subsector. Scholars defined artisanal fishery as a traditional or crude system of fishing which employs a very low level of technology [8]. The common fish species produced in Nigeria include Torpedo-shaped catfishes (Clarias spp.), Tilapias (hemichromis/ oreochromis. spp), Smoked fishes, Torpedo-shaped catfishes (heterobranchus. spp), African carps (cyprinidae), Marine fishes (osteichthyes) Elephantsnout (mormyridae, gnathonems spp.) Nile/Niger perch (lates niloticus), Bonga shad (ethmalosa fimbriata), Torpedo-shaped catfishes (clarias lazera) and Bonytongue fishes (heterotis spp.) [1].

Among all the fish species mentioned, this study is interested in the African catfish (Clarias gariepinus). African catfish is a diverse group of ray-finned fish known by its prominent barbells and is considered to be one of the most important tropical catfish species for aquaculture in West Africa [9, 10]. In Nigeria, catfish farming is proving to be a lucrative option for small-scale inland fisheries and the consumption of its products is on the increase [6].

The production of fish as an economic resource is undertaking by a good number of people especially the small scale farmers in Nigeria [10]. Therefore, to create a system with good returns, one needs good and continuous management policies directed towards efficient use of resources as this will not only sustain fisheries but will also heighten the level of food security in our society. For a sustained production and supply of fish and its other products, there is a need to investigate the managerial ability of the fish farmers otherwise called resource use efficiency. The importance of this assessment cannot be overemphasized seen that productive resources are scarce and expensive yet continuous supply must be maintained. The resources needed in fish production in the study area include land for pond construction and building, labour, capital and other production and maintenance inputs. The input market to support fish production is poorly developed or nonexistent. Most farmers have little or no access to credit to supply the required quantity of fingerlings, feeds, among others. The resultant effect is low productivity which makes it difficult to rise above the vicious cycle of poverty and improve the standard of living of the fishing household. The researchers, therefore, deemed it necessary to:

1) examine the socioeconomic characteristics of the farmers,

2) determine the costs and returns of fish farming,

3 ) estimate the production function and the determinants of the returns from fish farming,

4) evaluate the resource use efficiency of the farmers, and

5) identify the challenges facing fish farmers in the study area.

\section{Review of Related Literature}

Much scholarly work supports resource use efficiency of fish farmers both in Nigeria and around the globe. A study was carried out on comparative analysis of technical efficiency of catfish farms using different technologies in Lagos State, Nigeria. The findings show that the profit realized from earthen, cage and plastic pond was 41,904 USD, 5,441 USD, and 9,841 USD respectively at $\$ 380$ per USD. Their study equally revealed that the determinants of productivity were sex, age, and marital status [12]. Also, analysis of artisanal fishing operations in Degema Local Government Area of Rivers State, Nigeria reported that the majority $(86.7 \%)$ of the farmers are male with a household size within $6-10$ people $(53.0 \%)$. The study equally shows that a greater proportion $(30.0 \%)$ of the farmers are within the age of $40-49$ years, and $55.6 \%$ of them have been into the enterprise for over 15 years. As high as $42.3 \%$ of the farmers attended secondary school. The study further shows that the farmers averagely realized 181 USD profit from the enterprise [5]. Furthermore, Cobb Douglas was the lead equation in their result with labour, capital, operating cost, farming experience, level of education and household size been the significant exogenous variables. Not minding $65.6 \%$ of the farmers reporting storage facility as their major challenge [5].

A survey on the profitability analysis of fish production from concrete pond system in Benue State, Nigeria reported that the greater number of the farmers are above 50 years. Also, the study further revealed $50.8 \%$ have $1-5$ years farming experience, $40.8 \%$ attended tertiary education, $50.8 \%$ have a household size between $6-10$ people, and the mean pond size was $35 \mathrm{~m}^{2}$ [3]. The study reported 432 USD as the profit realized from the enterprise. The explanatory variables significant to the production function were; pond size, feed, and fingerling, while the determinant of productivity among farmers were; age, farming experience, household size, number of extension contact, and annual 
income [3]. Furthermore, Unekwwu et al. on the assessment of the constraints to catfish farming in Kogi State, Nigeria revealed that the mean age and farming experience was 46 years and 5 years respectively [13]. The major problems challenging catfish farming in the area were inadequate finance, high cost of feed, predators, marketing challenge, poor storage facilities, lack of government support, and high cost of transportation, disease, and high temperature.

\section{Resource Use Efficiency}

Resource use efficiency is either measured by simple input-output ratio or using Cobb Douglas functional form. Measurement in terms of input-output ratio depends on the individual contributions of each resource used. Efficiency of resource use can also be defined as the ability to derive maximum output per unit of resources $[14,15]$, which is the key to effectively address the challenges of achieving food security when resources are stock or supply of money, materials, staff, and other assets that can be drawn on by a person or organization. Resource productivity is a concept that is used to mean allocation of resources such as land, labour, capital, management and water for irrigation between competing alternative [16]. This resource productivity has remained a very complex concept and most difficult to interpret in the agricultural sector $[17,18]$ due to the diversity of capital being utilized in production, this suggests that, the use of each factor of production should not depend solely on its availability [19]. It is therefore necessary for the rural farmers to be abreast with the knowledge of resource allocation or allocative efficiency in agricultural production to help bring about increased agricultural productivity [20, 21]. Researchers have suggested that poor technical knowledge might be hindering the production and productivity of rural farmers due to poor understanding about the efficient resource allocation [15].

Measuring efficiency is very important in the use of scarce resources in the production process [22]. Combining production inputs efficiently to yield output is the primary task of a farm manager. When two firms in the industry use the same level of inputs and employ the same technology, and produce a different volume of output, it is an indication that at least one of the firm is producing inefficiently. Scholars should, therefore, concentrate on evaluating the efficiency of different fish production system with a view of identifying the most economically viable one for fish sustainability. Other authors assumed that efficiency is the same as optimal productivity since it is the index of the value of total farm output to the value of total resource utilized in the production process [23]. Far back in late 90s, Adesina and Djato opined that the optimal productivity of resources implies efficient utilization of the alternative resources available in the production process [24]. The existence of efficiency is in three forms which are technical, allocative and economic efficiency, despite that this study centres on allocative efficiency, it is worthy to define the three for academic contribution.

The measurement of a farm's technical efficiency is based on deviations of observed production from the efficient frontier. The ratio of the potential production to actual production defines the level of efficiency of the individual farm [25]. Technical efficiency is the measure of a firm's success in producing a maximum level of output from a given set of inputs. Also, technical efficiency describes the ability of a firm to achieve a higher level of physical output given a small level of production input [26]. On the other hand, allocative efficiency as the extent to which firms make an efficient decision in the use of input to the level which the value of the marginal contribution to production is equal to their marginal factor cost [27]. Allocative efficiency is equally the measure of a firm's success in choosing an optimal set of production inputs. Furthermore, economic efficiency is the product of technical and allocative (price) efficiency.

\section{Materials and Methods}

\section{The Study Area}

The study was conducted in Ogbaru Local Government Area of Anambra State, Nigeria. Anambra State is one of the 36 States in Nigeria, it is located in the South-Eastern part of the country, and comprises of 21 Local Government Areas (LGAs). The State is sub-divided into four agricultural zones to aid planning and rural development. Ogbaru is a humid $\left(23^{0}\right)$ tropical rain forest zone, it is located between longitude $6^{0} 31^{\mathrm{I}}$ and $7^{0} 03^{\mathrm{I}} \mathrm{E}$ and latitude $5^{0} 45^{\mathrm{I}}$ and $6^{0} 46^{\mathrm{I}} \mathrm{N}$. It has a boundary with Asaba in Delta State and Ndoni in River State. Ogbaru is located by the bank of River Niger. Ogbaru people are mainly fishermen and women, farmers and are traditionally known as warriors. The LGA has 16 communities which include: Atani, Akili-Ogidi, Akili-Ozizor, Amiyi, Mputu, Obeagwe, Ohita, Odekpe, Ogbakugba, Ochuche-Umuodu, Ossamala, Ogwu-Aniocha, Umunankwo, Umuzu, Okpoko and Ogwu-Ikpele. Atani is the LGA headquarter. Ogbaru is neighbored by Onitsha, a major commercial city in Southeast Nigeria and that gives Ogbaru people quick access to the market.

Sampling Technique and Sample Size.

All the communities in the LGAs were actively involved in the study. A multistage sampling technique was employed; in the first stage, 3 villages were randomly selected from each community to make it a total of 48 villages. In the second stage, 5 fish farmers were randomly sampled to realize a total of 240 farmers. Primary data was collected by the use of a well-structured questionnaire administered to the fish farmers through personal interview alongside personal observations by the researchers. The information sourced from the farmers includes background data of the respondents (occupation, farm size, extension contact, annual farm income, cooperative membership, access to credit, educational level, sex, age, household size and farming experience), variable inputs (feeds (kg), fingerlings (No), labour (man-day), and fertilizer $(\mathrm{kg})$ ), and fixed inputs (capital inputs, interest on a loan, depreciation on fish pond, electricity, and other equipment).

Methods of Data Analysis 
The study utilized a combination of analytical tools which include; descriptive statistics, budgetary methods, and inferential statistics. The objective $i$ and $v$ was achieved with descriptive statistics, objective ii was achieved with a budgetary method, objective iii was achieved with multiple regression analysis, and objective iv was achieved with allocative efficiency method. These models are mathematically defined as:

a) Budgetary method is defined as:

$$
\begin{gathered}
\mathrm{GM}=\mathrm{TR}-\mathrm{TVC} \\
\mathrm{NR}=\mathrm{TR}-\mathrm{TC} \\
\mathrm{TC}=\mathrm{TFC}+\mathrm{TVC}
\end{gathered}
$$

Where: GM is the gross margin, NR is the net returns, TR is the total revenue, TC is the total cost, TVC is the total variable cost, TFC is the total fixed cost. All the variables are measured in USD.

b) The multiple regression model defined by Ohajianya et $a l$. as the mathematical relationship between output and input factors is implicitly stated as:

$$
\mathrm{Y}=f\left(\mathrm{X}_{1}, \mathrm{X}_{2}, \mathrm{X}_{3}, \mathrm{X}_{4}, \mathrm{X}_{5}, \mathrm{X}_{6}, \mathrm{X}_{7}, \mathrm{e}\right)
$$

Where: $\mathrm{Y}$ is the total output produced $(\mathrm{kg}), \mathrm{X}_{1}$ is the pond size $\left(\mathrm{m}^{2}\right), \mathrm{X}_{2}$ is the utility (electricity and water cost) (USD), $X_{3}$ is the fingerling (Number of fish stocked), $X_{4}$ is the quantity of feed $(\mathrm{kg}), \mathrm{X}_{5}$ is the quantity of fertilizer $(\mathrm{kg}), \mathrm{X}_{6}$ is the capital input (depreciation on implements and fish pond) (USD), and $X_{7}$ is the labour input (mandays).

Four functional forms of the model; linear, exponential, semi-log, and double-log were tried and the lead equation selected based on the functional form with the best result that had the highest $\mathrm{R}^{2}$, t-ratios, highest number of significant variables, and in conformity to a priori expectations.

c) The researchers adopted the allocative efficiency method defined by Fasasi, Goni \& Baba and Awumyo-Victor as:

$$
\begin{aligned}
r & =\frac{\mathrm{MPP}_{\mathrm{xi}} * \mathrm{P}_{\mathrm{y}}}{\mathrm{P}_{\overline{\mathrm{x}}_{\mathrm{i}}}} \\
\mathrm{MVP} & =\mathrm{MPP}_{\mathrm{xi}} * \mathrm{P}_{\mathrm{y}} \\
\mathrm{MFC} & =\mathrm{P}_{\overline{\mathrm{X}}_{\mathrm{i}}}
\end{aligned}
$$

Where: $r$ is the efficiency ratio, MVP is the marginal value product (incremental contribution to revenue), $\mathrm{MPP}_{\mathrm{xi}}$ is the marginal physical product (coefficient), $\mathrm{P}_{\mathrm{y}}$ is the unit price of fish (output) in USD, MFC is the marginal factor cost, $\mathrm{P}$ is the unit price of input, and $\bar{X}_{l}$ is the geometric mean value of ith resources used. Note that, when: $r=1$ (implies efficient utilization of resources), $\mathrm{r}<1$ (implies over utilization of resources), and $r>1$ (implies under-utilization of resources). The relative percentage in MVP of each resource required for optimal resource allocation $(\mathrm{r}=1)$ defined in Mijindadi, and Ochi et al. was adopted as:

$$
\mathrm{D}=\left(1-\frac{\mathrm{P}_{\overline{\mathrm{x}}_{\mathrm{i}}}}{\mathrm{MPP}_{\mathrm{xi}} * \mathrm{P}_{\mathrm{y}}}\right) * 100
$$

Where: D is the percentage change in MVP

d) The multiple regression model for the relationship between net returns and socioeconomic variables is implicitly defined as:

$$
\mathrm{NR}=f\left(\mathrm{Z}_{1}, \mathrm{Z}_{2}, \mathrm{Z}_{3}, \mathrm{Z}_{4}, \mathrm{Z}_{5}, \mathrm{Z}_{6}, \mathrm{Z}_{7}, \mathrm{Z}_{8}, \mathrm{e}\right)
$$

Where; $N R=$ net return (USD), $Z_{1}=$ sex (dummy, Male = 1; Female $=2$ ), $Z_{2}=$ age (years), $Z_{3}=$ farming experience (years), $Z_{4}=$ level of education (years), $Z_{5}=$ marital status (dummy; married $=1$, otherwise $=0), Z_{6}=$ household size (Number of persons), $Z_{7}=$ cooperative membership (dummy, member $=1$, not a member $=0), Z_{8}=$ occupation (dummy, full time $=1$, part-time $=0$ ) and $\mathrm{e}=$ error term.

\section{Results Discussion}

\section{Socioeconomic characteristics of fish farmers}

Table 1 reflects the socioeconomic characteristics of the farmers in the area, the study revealed that fish farming is dominated by male farmers with $72.1 \%$, this male dominance in the enterprise is in agreement with the finding of Tasie et al. with $55.8 \%$ of them married, been married also helps to increase the supply of family labour [5]. The majority (53.5\%) of the farmers are within the age of 38-57 years, while the remaining $27.9 \%$ and $18.6 \%$ are within the age of $\leq 37$ years, and $\geq 58$ years respectively. The mean age of 46 years is an indication that the farmers are still in their active farm age with an average farming experience of 13 years. This result in age is in agreement with Unekwu et al. [13]. The study shows that greater proportion of the farmer's household size fall within $>11$ people, while the remaining $30.2 \%$ and $27.9 \%$ have household size within the range of 6-10 people and 1-5 people respectively. The mean household size was 11 people, large enough to increase the supply of family labour in the enterprise.

The study equally revealed that greater number $(37.2 \%)$ of the farmers attended secondary school, while the remaining $27.9 \%$, $18.6 \%$, and $11.6 \%$ attended Tertiary education, Primary education and postgraduate respectively. Only $4.7 \%$ of the farmers had no formal education. The average years the farmers spent in school was 11 years and agreed with [5]. Hence the farmers averagely attended secondary school, it means they are fairly literate and will be able to adopt agricultural technology. A greater number $(48.8 \%)$ of the farmers are primarily traders, while the remaining $39.5 \%$ and $11.6 \%$ are primarily farmers and civil servants. This result reveals the true nature of the study area as artisanal fishing (fishing in the wild) is often practiced in the area while only those not fully engaged in agriculture might attempt fish farming. $81.4 \%$ of the farmers practice catfish farming with concrete ponds while the remaining $18.6 \%$ uses earthen ponds, with the annual mean fish output of 5.297 tons. This result corroborates Oluwatayo \& Adedeji [12]. Furthermore, $67.4 \%$ of the farmers rear Clarias/Heterobranchus to corroborate with the study of Otubusin [6]. 
Table 1. Socioeconomic characteristics of fish farmers.

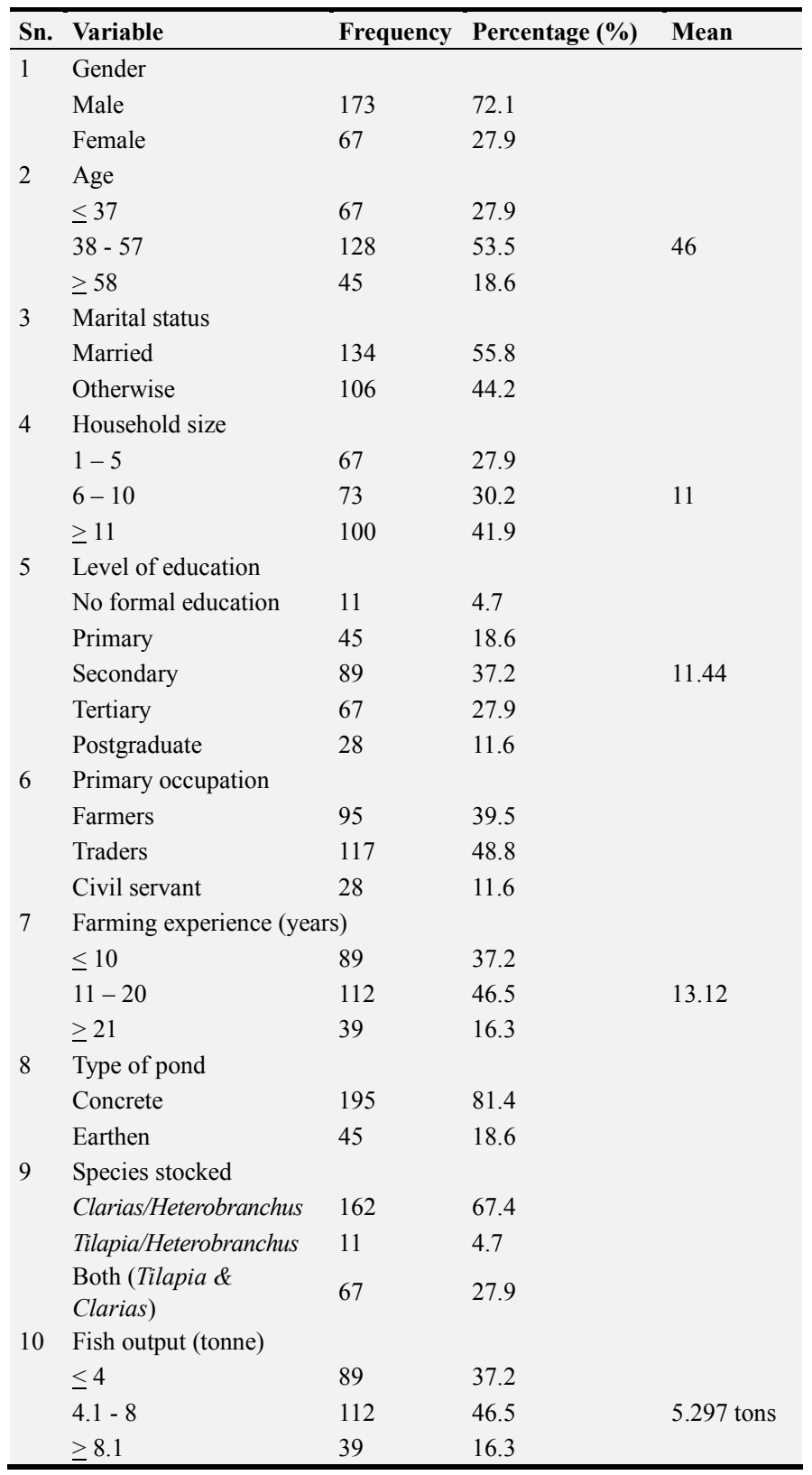

Source: Field Survey Data, 2020.

\section{Costs and Returns of Fish Farming}

The researchers adopted the US dollar to attain international standard and ease of readability across the globe. Table 2 represents the profit realized from fish farming in Nigeria. A sales revenue of 7,839.56 USD was reported, while the total cost incurred by the enterprise was $2,782.54$ USD. The gross margin of 5,253.13 USD and net returns of $5,057.02$ USD is an indication that fish farming is profitable which justifies the assertion of FAO and Giwa et al that reported an estimated annual per capita fish consumption of $17.5 \mathrm{~kg}$ and $43.9 \%$ demand-supply deficit $[1,4]$. The profit realized was also in agreement with Oluwatayo \& Adedeji [12]. The BCR of 2.82 is an indication that the profit realized can finance the next production 2.82 times. Also, the ROI of 1.82 implies that for every 1 USD investment made will generate 1.82 USD profit in return.

Table 2. Cost and returns of fish farming.

\begin{tabular}{llll}
\hline Item & Quantity & Price (USD) & $\begin{array}{l}\text { Value } \\
\text { (USD/farmer) }\end{array}$ \\
\hline Total Revenue & & & \\
Sales of fish (kg) & 5297 & 1.48 & $7,839.56$ \\
Variable Cost & & & \\
Labour (Man-day) & 109.68 & 0.78 & 85.55 \\
Medication & - & & 33.19 \\
Transportation & - & & 34.75 \\
Utility & - & & 167.93 \\
Fingerlings & 4286.6 & 0.05 & 214.33 \\
Feed (kg) & 316.44 & 4.66 & $1,474.61$ \\
Fertilizer (kg) & 124.42 & 4.63 & 576.06 \\
Total Variable Cost (TVC) & & & $2,586.43$ \\
Fixed Cost & & & \\
Depreciation on Capital Items & & & 145.02 \\
Depreciation on Fish Pond & 37.44 & & 51.09 \\
Total Fixed Cost (TFC) & & & 196.11 \\
Total Cost (TC) & & & $2,782.54$ \\
Gross margin (GM) & & & $5,253.13$ \\
Net returns (NR) & & $5,057.02$ \\
Benefit-cost ratio (BCR) & & 2.82 \\
Return on investment (ROI) & & & 1.82 \\
\hline
\end{tabular}

Source: Field Survey Data, 2020.

\section{Estimation of production functions of fish farmers.}

The double-log functional form had a better result with the highest $\mathrm{R}^{2}$ (0.756), more number of significant variables (tratios) and in conformity with the a-prior expectation was chosen as the lead equation (Table 3). The coefficient of multiple determinants; $\mathrm{R}^{2}(0.756)$ implies that $75.6 \%$ of the fish output was explained by the joint action of the explanatory variables (production factors) while the remaining $24.4 \%$ unexplained was as a result of the error beyond the control of the farmers. The lead equation is therefore defined as:

$$
\begin{gathered}
\mathrm{LnY}=0.123+0.089 \operatorname{LnX}_{1}+0.082 \operatorname{LnX}_{2}+0.736 \operatorname{LnX}_{3}+ \\
0.161 \operatorname{LnX}_{4}-0.017 \operatorname{LnX}_{5}+0.35 \operatorname{LnX}_{6}-0.141 \operatorname{LnX}_{7} .
\end{gathered}
$$

The coefficient of pond size $(0.089)$ was positive and significant at $5 \%$ alpha level of probability, this implies that a unit increase in pond size will increase fish output by 0.089 unit. Pond size contributed $471 \mathrm{~kg}$ to the total fish output of $5297 \mathrm{~kg}$ (Table 2). The coefficient of utilities (0.082) was positive and significant at $5 \%$ alpha level of probability, this implying that a unit increase in the amount spent on utilities by the farmers will increase fish output by 0.082 unit, these utilities include; water and electricity. The finding is in agreement with Tasie et al. Utilities contributed to the total fish output by $434 \mathrm{~kg}$. The coefficient of fingerlings (0.736) was positive and significant $1 \%$ alpha level of probability, this implies that a unit increase in the number of fingerling stocked will increase the fish output by 0.736 unit. The number of fingerlings stocked contributed to the total fish output by $3899 \mathrm{~kg}$, the high-value contribution by fingerlings could be attributed to a good breed stock.

Also, the coefficient of feed $(0.161)$ was positive and significant at $5 \%$ alpha level of probability, this implies that a 
unit increase in the quantity of feed used will directly increase the fish output by 0.161 unit. Feed contributed $853 \mathrm{~kg}$ to the total weight of the fish produced by the farmers. The coefficient of fertilizer (0.017) was negative and significant at $5 \%$ alpha level of probability, this implies that a unit increase in the quantity of fertilizer used by the farmers will reduce fish output by 0.017 unit. Fertilizer reduced the weight of total fish produced by $90 \mathrm{~kg}$. Furthermore, the coefficient of labour (0.141) was negative and significant at $1 \%$ alpha level of probability, this implies that an increase in labour employed in fish farming will reduce output by 0.141 unit. This findings aligned with the study of Tasie et al. Labour reduced total fish output by $747 \mathrm{~kg}$. This is an indication that many workers on the farm are idle and their impact is not being felt in the enterprise.

Table 3. Estimation of production functions of fish farmers.

\begin{tabular}{|c|c|c|c|c|}
\hline Explanatory variable & Linear & Exponential & Semi log & Double log \\
\hline Constant & $-156.26(-0.33)$ & $7.268(39.48)$ & $-16028.768(1.68)$ & $0.123(0.10)$ \\
\hline Pond size $\left(\mathrm{M}^{2}\right)$ & $14.847(2.88)^{* * *}$ & $0.001(2.28)^{* *}$ & $3340.845(2.74)^{* *}$ & $0.089(2.64)^{* *}$ \\
\hline Utilities (USD) & $0.011(2.53)^{* *}$ & $3.993(1.97)^{* *}$ & $541.755(0.77)$ & $0.082(1.99)^{* *}$ \\
\hline Feed $(\mathrm{kg})$ & $1.743(4.63)^{* * *}$ & $1.002(1.14)$ & $305.99(0.51)$ & $0.161(2.12)^{* *}$ \\
\hline Fertilizer (kg) & $0.412(0.65)$ & $0.001(1.73)^{*}$ & $-76.297(1.06)$ & $-0.017(1.97)^{* *}$ \\
\hline Capital depreciation (USD) & $0.001(0.64)$ & $5.015(1.25)$ & $-156.724(-0.39)$ & $0.35(0.69)$ \\
\hline $\mathrm{R}^{2}$ & 0.738 & 0.674 & 0.643 & 0.756 \\
\hline F-values & $110.55 * * *$ & $35.43 * * *$ & $46.79 * * *$ & $124.78 * * *$ \\
\hline Sample size & 240 & 240 & 240 & 240 \\
\hline
\end{tabular}

Source: Field Survey Data, 2020. Figures in parenthesis are $\mathrm{t}-$ ratios $(*)$ significant at $10 \%,(* *)$ significant at $5 \%$, and $(* * *)$ significant at $1 \%$.

\section{Resource Use Efficiency of Fish Farmers}

The resource use efficiency of the farmers presented in Table 4 was computed from the lead equation (Cobb Douglas) in relation with inputs and outputs (Table 3). The result shows that major inputs in catfish farming such as pond size, utilities, feed, fertilizer, capital depreciation, and labour were overused and the farm managers need to decrease their cost for its optimum allocation. The study equally revealed that fingerlings were under-used, this suggests the need to increase the cost of fingerlings by at least $95 \%$ for optimum resource allocation. A better argument might be put forth that the farmers are not aware of stocking rate, the researchers, therefore, call on the agricultural extension agents to organize training on fingerlings stocking rate among other innovative measures needed to improve performance in the industry. The farmers may still organize themselves into a cooperative to ensure networking for easy access to information. Being that the ratio of MVP (Marginal Value Product) to MFC (Marginal Factor Cost) was less than one for all the resources used in fish farming apart from fingerlings cost which was greater than one, the researcher opined that resources are not used for optimum economic advantage, we further call for an adjustment in the marginal value product of all the resources to ensure optimal use.

Table 4. Resource use efficiency of fish farmers.

\begin{tabular}{|c|c|c|c|c|c|c|c|}
\hline Variables & $\mathbf{M P P}_{\mathbf{x i}}$ & MVP & Mean input & MFC & $\mathbf{r}$ & D-value & Efficiency \\
\hline Pond size & 0.089 & 0.13 & 37.44 & 1.36 & 0.10 & 936 & Over-used \\
\hline Fingerlings & 0.736 & 1.09 & 4286.6 & 0.05 & 20.61 & 95 & Under-used \\
\hline Utility & 0.082 & 0.12 & 1 & 1.00 & 0.12 & 724 & Over-used \\
\hline Feed & 0.161 & 0.24 & 316.44 & 4.66 & 0.05 & 1857 & Over-used \\
\hline Fertilizer & -0.017 & -0.03 & 124.42 & 4.63 & -0.01 & 18502 & Over-used \\
\hline Capital dep. & 0.35 & 0.52 & 240 & 1.00 & 0.52 & 93 & Over-used \\
\hline Labour & -0.141 & -0.21 & 109.68 & 0.78 & -0.27 & 473 & Over-used \\
\hline
\end{tabular}

Source: Field Survey Data, 2020. Mean price of output: 1.48 USD.

\section{Determinants of Net Returns of Fish Farming.}

Table 5 reflects the relationship between the net returns and farmer's socioeconomic characteristic analyzed with a multiple regression to produce the best result. Semi-log had the best result with $\mathrm{R}^{2}$ of 0.632 , implying that $63.2 \%$ variation in net returns was explained by the explanatory variables (socioeconomic variables) while the remaining $36.8 \%$ was as a result of the error beyond the control of the farmers. The F-value of 3.23 shows the general significance of the model distribution at $1 \%$ alpha level of probability. The coefficient of sex $(0.1448)$ was negative and significant at $5 \%$ alpha level of probability, this implies a shift on sex target say from male to female farmers will reduce net returns by 0.1448 unit. The negative relationship between sex and net returns reduced the total net returns (Table 2) realizable with 732.26 USD. These findings could be attributed to the physicality and the rigorous jobs required in the enterprise. The significance of sex was expected and is consistent with Oluwatayo \& Adedeji.

Also, the coefficient of farming experience (0.2682) was positive and significant at $1 \%$ alpha level of probability, this implies that a unit increase the number of years the farmers spend in fish farming will increase the net return by 0.2682 unit. The farming experience contributed 1,356.29 USD to 
the total profit from the enterprise. More experienced farmers are by every means expected to perform better than less experienced farmers. This result is in agreement with Penda et al., Tasie et al., and Unekwu et al. The coefficient of the level of educational (0.5149) was positive and significant at $5 \%$ alpha level of probability, this implies that a unit increase in the number of years the farmers spend in school will increase net returns by 0.5149 unit. Level of education contributed 2,603.86 USD to the total profit from fish farming in the industry. This result was expected as the extent of agricultural technology adoption is easier with an increased years of schooling. This finding was in agreement with Penda et al. and Taie et al.

Furthermore, the coefficient of household size (0.1777) was negative and significant at 5\% alpha level of probability, this implies that a unit increase in the number of household people will reduce net returns by 0.1777 unit. Household size reduced the profit realizable by 898.83 USD. This result was expected as more number of the fish produced will be used for home consumption. The finding is equally in agreement with Penda et al., Tasie et al., and Unekwu et al. Finally, the coefficient of primary occupation (0.0407) was negative and significant at $5 \%$ alpha level of probability, this implies that as the number of fish farmers that are not primarily engaged in agriculture increases, net returns will reduce by 0.0407 unit. Primary occupation reduced total profit by 205.75 USD. A farmer who is not $100 \%$ committed to the industry may not be able to put in their best as this will harm profit.

Table 5. Determinants of net returns of fish farming.

\begin{tabular}{|c|c|c|c|c|}
\hline Explanatory variables & Linear & Exponential & Semi-log & Double-log \\
\hline Constant & $-4501328(-0.28)$ & $1359581(1.13)$ & $-3.6 \mathrm{E}+07(-1.01)$ & $-2.58338(-0.09)$ \\
\hline Sex & $0.1097(1.75)^{*}$ & $0.755718(1.63)$ & $0.1448(-2.25)^{* *}$ & $9.13713(1.98)^{* *}$ \\
\hline Age & $0.5748(1.51)$ & $0.0384(1.37)$ & $2.297(1.38)$ & $1.5613(1.28)$ \\
\hline Experience & $0.7349(-2.56)^{* *}$ & $-0.1015(1.83)^{*}$ & $0.2682(2.93)^{* * *}$ & $-1.2520(1.87)^{*}$ \\
\hline Level of education & $0.7349(1.49)$ & $0.0740(2.30)^{* *}$ & $0.5149(2.79)^{* *}$ & $0.5728(2.78) * *$ \\
\hline Marital status & $-0.0320(-0.30)$ & $-0.7584(-0.97)$ & $11.1597(0.10)$ & $-5.395(-0.67)$ \\
\hline Household size & $0.3274(2.43)^{* *}$ & $0.2378(2.39)^{* *}$ & $-0.1777(2.63)^{* *}$ & $1.3372(2.70)^{* *}$ \\
\hline Primary occupation & $0.0350(0.78)$ & $0.2432(0.73)$ & $0.0407(-2.34)^{* *}$ & $3.1084(0.93)$ \\
\hline $\mathrm{R}^{2}$ & 0.3912 & 0.3780 & 0.6321 & 0.4275 \\
\hline $\mathrm{F}$ - ratio & $2.72 * *$ & $2.58 * *$ & $3.23 * * *$ & $3.17 * * *$ \\
\hline Sample size & 240 & 240 & 240 & 240 \\
\hline
\end{tabular}

Source: Field Survey Data, 2020. Figures in parentheses are the t-ratios, $(*)$ significant at $10 \%,(* *)$ significant at $5 \%$, and $(* * *)$ significant at $1 \%$.

\section{Challenges Faced by Fish Farmers}

Table 6 represents the challenges faced by fish farmers in Nigeria, due diversity of challenges facing fish farming sector of agriculture, the researchers allowed for multiple responses. The challenges were ranked to enable the policymakers to identify those that need urgent attention. From the 10 challenges captured, the first five that may need urgent policy interventions include; high cost of feed $(88.3 \%)$, inadequate capital $(82.5 \%)$, poor management $(52.5 \%)$, poor of extension services $(41.7 \%)$, and high cost of labour (31.7\%). A belief in the improvement of the identified challenges will improve the farmer's ability for optimum resource allocation. These findings were in agreement with Tasie et al. and Unekwu et al.

Table 6. Challenges Faced by Fish Farmers.

\begin{tabular}{lllll}
\hline Sn. & Identified constraints & Frequency & Percentage\% & Ranking \\
\hline 1 & Lack of infrastructure & 18 & 7.5 & 10.0 \\
2 & Lack of government support & 24 & 20.0 & 9 \\
3 & Pest and disease & 48 & 22.5 & 8 \\
4 & Poor veterinary & 54 & 27.9 & 7 \\
5 & Lack of storage facility & 67 & 31.7 & 6 \\
6 & High cost of labour & 76 & 41.7 & 5 \\
7 & Poor of extension services & 100 & 52.5 & 3 \\
8 & Poor management & 126 & 82.5 \\
9 & Inadequate capital & 198 & 88.3 \\
\hline
\end{tabular}

Source: Field Survey Data, 2020. (*) Multiple responses were recorded.

\section{Conclusion and Recommendations}

The recent COVID-19 pandemic forced many industries to lay-off workers. The world is also battling with the economic challenges and no nation is exempted from the devastating effect of the pandemic, while many countries have deported foreigners as the few jobs available may not be enough for her citizens. Also, the agricultural sector has been predicted by many scholars as the only economic sector that will continue to absorb the labour force since food security is still a global problem, especially in developing countries. To attain self-sufficiency in food supply especially among those rich in proteins, farmers in developing countries like Nigeria are advised to venture into fish farming since it is one of the cheapest sources of non-plant protein. It is therefore 
important to understand the farmer's ability to allocate scarce resources that will lead to maximum profit. Every participant in the agricultural sector should know the exact time to vary production inputs. This study on the analysis of the resource management ability of catfish farmers in Nigeria is therefore necessary at this time. An understanding of this concept, as well as the challenges inherent in the industry, will help policymakers to further advice on the way forward. The study, therefore, presents the following recommendations:

1) Governmental and non-governmental agencies should please help to subsidize the cost of inputs needed in the fishing industry.

2) Extension agents should be engaged to train the farmers especially in the areas of stocking rate and other relevant technologies

3) Farmers should be sensitized on the need to take agriculture as their primary occupation to avoid unnecessary distractions created by engaging in other activities

4) Women should be empowered to key into fish farming, this will help to reduce male dominance and introduce healthy competition.

\section{References}

[1] Giwa E. J., Jim-Saiki L., Adeyemo A. M., Unah RL., Waniko S. N, Ogunbadejo H. K. \& Alhaji T. (2018). Short-term prediction of fish production in Nigeria: Empirical study Nigeria fish demand and supply. International Journal of Advanced Multidisciplinary Research, 5 (9), 28-37. DOI: 10.22192/ijamr.

[2] FDF (2018). Report of Presidential Committee on Fisheries and Aquaculture Development. Federal Department of Fisheries, Federal Ministry of Agriculture Nigeria and New York Science Journal, 2020; 13 (2). Retrieved from http://www.sciencepub.net/newyork

[3] Penda S. T., Unaji G. P. \& Odoenmenem I. U. (2013) Profitability analysis of fish production from concrete pond system in Benue State, Nigeria. International Journal of Research in Social Sciences, 2 (4), 64-70.

[4] Food and Agriculture Organization (2018). The Nigeria country Brief and the FAO Fishery and Aquaculture Statistics. Accessed online from https://www.fao.org on 11/7/19.

[5] Tasie C. M., Wilcox G. I. \& Kalio A. E. (2020). Analysis of artisanal fishing operations in Degema Local Government Area of Rivers State, Nigeria. New York Science Journal, 13 (2), 85-91.

[6] Otubusin, S. O. (2011). An inaugural lecture: Fish! Fish!! Fish!!! Department of Aquaculture and Fisheries Management, College of Environmental Resource Management, University of Agriculture, Abeokuta, Ogun State, Nigeria, (pp: 45-55).

[7] FDF, 2005. Report of Presidential Committee on Fisheries and aquaculture Development, Consolidated Repot, vol. 1, 2005.

[8] Anene A., Ezeh C. I. \& Oputa C. O. (2010). Resource use and efficiency of artisanal fishing in Oguta, Imo State, Nigeria. Journal of Development and Agricultural Economics. 3, 94-99.
[9] Effiong M. U. \& Isaac I. N. (2019). Comparative study of the bacterial load and species diversity in the African catfish (Clarias gariepinus) cultured in contrasting aquaculture tanks in Uyo, Nigeria. Animal Research International, 16 (3), 34433449 .

[10] Amande T. J. \& Nwaka S. U. (2013). Bacterial flora of African catfish (Clarias gariepinus) harvested from ponds in Uyo South-South Nigeria. Journal of Environmental Science, Toxicology and Food Technology, 5 (3), 72-76.

[11] Oladejo A. J. (2010). Economic analysis of small-scale catfish farming in Ido Local Government Area of Oyo State, Nigeria. Agricultural Journal, 5 (6), 318-321.

[12] Oluwatayo I. B. \& Adedeji T. A. (2019). Comparative analysis of technical efficiency of catfish farms using different technologies in Lagos State, Nigeria: a Data Envelopment Analysis (DEA) approach. Agriculture \& Food Security, 8 (8), $1-9$.

[13] Unekwu O., Tijani A. A. \& Ojomugbokenyode E. (2020). Assessment of the constraints to catfish farming in Kogi State, Nigeria. Asian Research Journal of Agriculture, 12 (3), 39-46.

[14] Rahman S. A. \& Lawal A. B. (2003). Economic analysis of maize based cropping systems in Giwi Local Government Area of Kaduna State, Nigeria. International Journal of Agriculture. Science, Environment and Technology, 3 (2), 139-148.

[15] Mahesh S. \& Mahima B. (2018). Resource use efficiency analysis for potato production in Nepal. Journal of Nepal Agricultural Research Council, 4, 54-59. DOI: http://dx.doi.org/10.3126/jnarc.v4i1.19690

[16] Ohajianya DO, Onu PN, Ugwu JN, Osuji MN, Nwaiwu IU, Orebiyi JS, Godson-Ibeji CC, Enyia CO (2013). Technical efficiency of table egg producers in Imo State, Nigeria. Asian Journal of Agricultural Extension, Economics and Sociology 2 (2): 118-127.

[17] Azih I. (2008). A background analysis of the Nigerian agricultural sector (1998 to 2007). Oxfam NOVIB Economic Justice Campaign in Agriculture, November 2008, external financing and agricultural productivity in Nigeria. Accessed $\begin{array}{llll}\text { on } & 12 & \text { August } & 2020\end{array}$ https://www.researchgate.net/publication/3377

[18] Sule A. \& Yusuf A. (2019). External financing and agricultural productivity in Nigeria. Journal of Economics and Finance, 3 (1), 307-320.

[19] Obianefo C. A., Osuafor O. O., Ezeano C. I. \& Anumudu O. O. (2020). Mediation effect of adopting good agronomic practices on rice productivity in Anambra State, Nigeria. International journal of agriculture and rural development, 23 (1), 4913-4926.

[20] Wategire BB, Ike PC (2015). An analysis of the technical efficiency of non-motorized small scale Shrimp Fishers in the Coastal areas of Delta State, Nigeria. Mediterranean Journal of Social Sciences, 6 (1), 285-291.

[21] Obianefo C. A., Nwigwe C. A., Meludu T. N. \& Anyasie I. C. (2020). Technical efficiency of rice farmers in Anambra State value chain development programme. Journal of Development and Agricultural Economics, 12 (2), 67-74.

[22] Ayinde A., Okuneye P. A., Aromolaran A. B. \& Momoh S. (2017). Insecticide use efficiency in cowpea production in Nigeria. Journal of Sustainable Development, 2 (1), 36-44. 
[23] Sani A, Yakubu AA, Bello HM (2010). Resource-use efficiency in rice production under small scale irrigation in Bunkure Local Government Area of Kano State. Nigerian Journal of Basic and Applied Sciences. 18 (2): 292-296.

[24] Adesina A. A. \& Djato K. K. (1997). Relative efficiency of women as farm managers: Profit function analysis in Côte d'Ivoire. Agricultural Economics, 16 (1), 47-53.

[25] Kaliba A. R. \& Engle C. R. (2015). Productive efficiency of Catfish farms in Chicot County, Arkansas. Aquaculture Economics \& Management, (pp. 1-24). Aquaculture/Fisheries Center, University of Arkansas at Pine Bluff, 1200 North University Drive, Mail Slot 4912, Pine Bluff, AR 71603, USA.

[26] Kareem R. O., Dipeolu A. O., Aromolaran A. B \& AkegbejoSamson (2008). Analysis of technical, allocative and economic efficiency of different pond systems in Ogun state, Nigeria. African Journal of Agricultural Research, 3 (4), 246254.

[27] Oleg B., Michael F. \& Andreas S. (2006). Allocative efficiency measurement revisited: Do we really need input prices? Accessed 12 August 2020 from file:///C:/Users/JEKS/Downloads/Allocative_Efficiency_Meas urement_Revisited_Do_We_pdf

[28] Fasasi A. R. (2006). Resource use efficiency in yam production in Ondo State, Nigeria. Agric. J., 1 (2), 36-40.

[29] Goni M., Mohammed S. \& Baba B. A. (2007). Analysis of resource use efficiency in rice production in the Lake Chad area of Borno State, Nigeria. J. Sustain. Dev. Agric. Environ., $3(2), 31-37$.

[30] Awunyo-Victor D., Abawiera C. W. \& Aidoo R. (2016). Resource use efficiency among maize farmers in Ghana. Agric. \& Food Security, 5 (28), 1-10.

[31] Mijindadi N. B. (1980). Production efficiency on farms in Northern Nigeria. An unpublished Ph.D Thesis, Cornell University, U.S.A.

[32] Ochi J. E., Sani R. M. \& Idefoh F. K. (2015). Economic analysis of resource use efficiency among small scale cassava farmers in Nasarawa State, Nigeria: Implications for Agricultural Transformation Agenda. International Journal of Research in Agriculture and Forestry, 2 (2), 14-21. 